\title{
The Impact of Corporate Governance on Non Financial Performance in Jordanian Commercial Banks and Islamic Banks
}

\author{
Suleiman Hussein Al-Beshtawi ${ }^{1}$, Omar Mohammed Zraqat ${ }^{2} \&$ Hamdan Moh'D Al -Hiyasat ${ }^{2}$ \\ ${ }^{1}$ Accounting Dept., Faculty of Administrative \& Financial Sciences, AL-Israa University, Jordan \\ ${ }^{2}$ Accounting Dept., Faculty of Business Administration, The World Islamic Science University, Jordan \\ Correspondence: Dr. Suleiman Hussein Al-Beshtawi, Associate Professor, Accounting Dept., Faculty of \\ Administrative \& Financial Sciences, AL-Israa University, Jordan. E-mail: dr_sulieman@yahoo.com
}

Received: January 14, 2014

doi:10.5430/ijfr.v5n3p54
Accepted: March 20, 2014

Online Published: June 1, 2014

URL: http://dx.doi.org/10.5430/ijfr.v5n3p54

\begin{abstract}
This research was conducted in order to indicate the role of corporate governance in the commercial banks and Islamic banks in Jordan and its impact on financial and non-financial performance because of its positive effects on the improvement and development in the process of managerial decision-making through various development and modernization in the processes and stages of internal activities of banks and raise the level of performance.

The study sample included the society represented by all commercial banks and Islamic Jordan totalling (16Jordanian Banks).Where the study aimed to executive management, sections and departments on the Application of Corporate Governance in those banks as well as financial and accounting departments where.

The study found that commercial banks and Islamic banks in Jordan apply corporate governance through identified for its principles and its components and steps and provided specialized committees would activate the application of corporate governance. And recommended the need for greater attention to the competent authorities to monitor financial and non-financial performance of the departments of Jordanian banks and increase the provisions of the law and the necessary legislation imposed by the government and the competent application of corporate governance.
\end{abstract}

Keywords: corporate governance, non financial performance, Jordan

\section{Introduction}

Pat talk about corporate governance, regulations and laws imposed by the administration of financial companies in general and banks in particular, which include application where in the last two decades (Kayed, 2003, p7), takes a great deal of thinking in terms of a protective heeded when the departments of these companies and their government agencies relevant, especially in the absence of regulatory regimes, which is keen to provide appropriate safeguards to all recipients of financial accounting information and non-financial, especially those provided to them in reports or financial statements with credibility and consistency and neutrality.

The application of corporate governance at the Jordanian banks is one of the most important elements that supports the national economy and works to increase the capacity of administration in which to deal with related parties, whether in-house them or external, which called on the Central Bank of Jordan to the issuance of a special booklet governance institutional in Jordanian banks in order him to ensure the application of corporate governance efficiently and effectively because of its positive effects on the improvement and development in the process of decision-making various administrative and especially the ones credit, which will reflect positively on the evaluation of operating performance and conservative banks on their market share through the development and modernization of processes and stages of internal activities and building a special relationship with their customers through the services provided to them and the response time of the request.

Where it is noted that in the current era is no longer financial metrics for performance is the only foundation in building a picture of the position of the bank, but required the presence of integration between financial and non-financial metrics and compatible strategies to secure the banks future.

In order to achieve this theremust exist departments in charge of creating an environment surrounding the performance of the bank in terms of legal and legislature to improve relationships and increase confidence 
"Bmedkqa" accounts - especially after the scandals of global audit firms such as Enron America and VIVENDI European among others - shareholders, investors, customers and the local financial market and external. ... Etc., came the idea of creating the structure of corporate governance Organizational governance structures (OGS) and processes related to it as a way of scrutiny as a result of the scandals of corporate America at the end of 2001 and the fall of acute financial markets in 2002, and to invite the U.S. government to reconsider the legislation, creating the Securities and Exchange Commission and the Committee bourse (SEC) Securities and Exchange Commission, in the United States in order to preserve the interests of those parties with the banks and increase the confidence in their administrations. (Mirag and Abdul Hafeez, 2007, pp. 12-14) and (ESFRC, 2003)

\subsection{Problem of the Study}

To discuss the concept of corporate governance and its impact on non-financial performance and with the goal of making decisions on shareholders, employees and customers, as this has a direct impact on the continuity of the bank and maintained its market share and its financial position as well as the interaction of activities at different levels of management of Jordanian banks with the benefiting from the services of the bank, which has a positive impact on financial results of banks. Thus, the lack of conceptual coherence to the managers of these banks with non-financial metrics leads to not create a balance in the use of these standards in the formulation of the company's performance. As well as the impact on the survival and the continuation of the banks in the market competition, the problem of questions consisted of the following elements:

1 - Does identifying the elements and principles of corporate governance in Jordanian banks to ease implementation and achieving results?

2 - Are they affected by the non-financial performance for senior management in Jordanian banks where the application of corporate governance?

\subsection{Objective of the Study}

Came to focus on the application of corporate governance and its impact on financial and non-financial performance in order to identify the degree of access to and use of operational metrics by bank managers to ensure the improvement and development of performance and service delivery appropriate for their customers in addition to building relations with them and with shareholders, employees, and that keeps the loyalty and continuity in the delivery of services at best to take advantage of them by its users. In addition to increasing the awareness and confidence of accounting information between financial and non- financial and among its users.

\subsection{Importance of the Study}

Through Turning to more threads vital in terms of scientific research, but a corporate governance and its impact on non-financial performance of the departments of Jordanian banks through the study of the impact on the protection of administration to the interests of related parties of the shareholders, employees, customers and government agencies...etc. when making for operational decisions and direct reflection on the continuity of the banks in the business market and maintaining their market share and financial position, results of operations, as well as increase the loyalty of their employees and their customers by increasing their confidence in the services provided to them and the non-financial performance.

\subsection{Hypotheses of the Study}

The hypotheses of the study and concentration on the major hypotheses:

There is a statistically significant relationship between corporate governance and non-financial performance when discussing Jordanian commercial and Islamic banks.

In order to measure this hypothesis a subsidiary was formulated, as follows:

1 -Jordanian commercial banks and the Islamic banks do not apply corporate governance through identified for its principles and its components and steps.

2 - Non-financial performance of the higher level of management in Jordanian Commercial banks and the Islamic banks are not affected by application of Corporate Governance.

\section{Theoretical Framework}

Financial metrics of interest to managers in senior management as they represent the product of the financial reports for the financial accounting system and provide management with the necessary nutrition reverse to raise the efficiency of the financial performance in the future. While non-financial metrics of interest to managers in various departments in the bank refer to the Bank's activities in detail and represents the output feedback immediate aim to 
raise the efficiency of non-financial performance and reverse the behavioral impact on the adequacy of the performance of employees within the principles and elements of corporate governance. (Merchant, 1998, PP.72-73), (Innes \& others, 1994)

The stated interest in the application of corporate governance from cycle president in the integrity of the financial system and increase its ability to beat the competition prevailing in the financial markets, as well as the mind of the tools of high importance that enable the management of Jordanian banks to maintain its shareholders, employees and customers and increase their loyalty and confidence in their performance, it which is reflected directly on the market share of these banks and continuity in the business market and increase their profits. So it had to be on those departments of increased attention scales non-financial performance along with those financial measures of performance, including an attempt to develop and improve its performance and its relationship with related parties.

Al-Bashir (2003) Indicated the importance of having a corporate governance to increase the entity's ability to achieve its objectives within a specific framework stems from the inside as an institution based on the law and the rules of procedure and the administrative structure is clear powers and responsibilities and justice in the application of regulations, instructions and so on all levels of management and labor without being influenced by the individual or the person that is the cursor on the continuation of the business and progress.

Highlighting the financial and accounting scandals of modern companies in the United States, such as (Enron) and (worldcom) and (Xerox) big questions about the credibility of corporate governance and its relationship to the profession of accounting and auditing. The manipulation and fraud that took place in these companies has a negative impact on both investors and employees, banks, creditors and the telecommunications sector and technology, and the stock market, and the government and the auditors, and the U.S. economy in general. Investors will need a long time to restore confidence in the institutions of America, and auditing firms. Which requires a fundamental re-examination of the relationships between the auditors and management of private companies' Board of Directors. In our opinion, the solution lies not in applying laws, but the solution is in improving the ethics of the implementers of these laws, whether they are based on the application of corporate governance or auditors. (Dahmash and Abu Zer, 2003)

\subsection{The Concept of Corporate Governance}

Corporate governance, is only a set of procedures used by the representatives of the stakeholders in the bank "Kalmsahmin", employees and others..., in order to provide supervision of the risks posed by management. Has been described by the report issued by the Cadburg in 1992 that effectively exercised by boards of directors to increase the efficiency and effectiveness of performance of departments in achieving its objectives and service related parties company's internal and breakers which determine the competitive position and rely on the state's economy (University of Technology Sydney, VTS, 2002)

Have known each (UNDP 1997) (FRECHETTE, 1999) as the application imposed by the relevant economic, political and administrative at all levels in order to hear the reaction of the related parties with it.

The World Bank has been known to control the institutional framework through which they operate financial institutions in order to create harmony between the interests of the institutions and the interests of the relevant parties with them. (Slivia \& Amoro, 2005, p1)

The Arab Society of Certified Public Accountants focused in its definition of institutional control on the side of control and evaluate the performance of corporate management. (ASCA, 2006, p.5)

While the Union of Arab Banks defined to control institutional focuses on the integration between the law and the performance of good governance in the companies, which works to attract both human capital and optimal use of resources and to meet the wishes of the related parties with the company in order to achieve the economic value and the continuity of the company in the long term. (Union of Arab Banks, 2003, p40-42)

The (Juma, 2003, p6) and (Maher, 2007, p 543) were he was known as the system includes the procedures, rules and which they operate corporate governance in order to improve its financial performance by taking decisions that serve shareholders, stakeholders and the community to maintain the company's reputation in the markets Business.

Came corporate governance concept requires the application of a set of principles that have an active role in ensuring that the administration to its operational and financial governance that would preserve the company's resources and relationships with related parties represented in: (Dahmash and Abu Zer, 2003, p3)

1 - The responsibility of the board of directors in selecting the most qualified senior management and morals and monitor their performance.

2 - Management's responsibility in the preparation of financial statements reflect the financial position and its 
results of its operations and prepare the necessary disclosure to interested parties in a timely manner.

3 - The responsibility of the audit committee and the board of directors in the use of an independent auditing firm to get a professional opinion from a neutral business and financial position of the company.

4 - The responsibility of the audit company for confirmation on her true independence and without any conflicts of interests. And possession of qualified cadres operating in accordance with the standards and accounting principles and generally accepted auditing.

5 - The company's responsibility in dealing with its employees fairly and equally.

Through previous definitions to control institutional researchers argue that corporate governance is only the system determines the Department's work to raise their efficiency and increase their competitiveness in the markets business, and through the protection of related parties with the bank, headed by the shareholders, creditors, customers and other parties and to provide them with data and financial information and non- financial resources needed to achieve the trust and credibility the bank administration and performance, which will impact on the improvement of the financial position of the Bank and maintained its market share as well as to increase that share by attracting new customers joined the Bank's customers by comparing them to the performance provided by other banks and characterize the bank's management to perform their services with developed and continually improved.

2.2 The Role of the Application of Corporate Governance and Its Impact on the Development and Improvement of the Financial and the Non-Financial Performance

A group of researchers emphasized the importance of the application of corporate governance in companies of all types because of its active role in the development and improvement of the performance of financial management and other financial and its impact on the financial market and market share. Has confirmed (Hamaple, 1998) on the importance of corporate governance by proposing a committee on the application of the principles and elements of corporate governance in UK companies, after having achieved the companies that apply corporate governance success in the business market. He also stressed that the Board of Directors of a prominent major role in influencing management decisions and control in companies.

Nakomura (2001) has made it clear mechanism to apply corporate governance in companies and Japanese banks and its impact on the Japanese economy, taking into account the economic effects of different influencing the business market and the companies in it. Has also study a comparison of the companies applied to control institutional in Japan with their counterparts in European and American countries and British.

He has Nagel and Rigayuso, (2003) to study the importance of the application of corporate governance through the application of Balanced Scorecard to evaluate the performance of financial and non- financial companies, which shows the work of both management and data for decision-making of financial and non-financial through the axes of the card four (financial, operations and phases of Interior, customers, learning and growth). The study of the four axes of the card describes the relationship of senior management and the Board of Directors to apply corporate governance and its impact on various administrative decisions, whether it's financial or non-financial. The study concluded that it must provide temporary credibility in the information and data to help decision-makers to perform different jobs and that is reflected directly on increasing the efficiency and effectiveness of internal control systems.

The application of institutional control in Jordanian banks need to be subject to the laws and regulations that define the relationship between the management of those banks and related parties with bank stocks and a campaign staff, creditors, customers and others... In order to monitor the performance of these departments to ensure efficiency and effectiveness whether reminded of the financial or non-financial. On this basis, the Corporate Governance presented a set of questions on the management of these banks to answer the most important: (http://ar.Ipedia.org /wikiwik)

1 - How can shareholders access to the conviction and the confidence of management performance in terms of their use and the optimal exploitation of the resources of the bank of the money?

2 - How can shareholders access to the conviction and the confidence of management performance in terms of maximizing the profitability of the bank and increase the nominal value of its shares?

3 - How can shareholders access to the conviction and the confidence of the efficient and effective performance management in general?

4 - How can knowledge management performance with respect to them making decisions related to society and the environment?

To the application of corporate governance in banks of Jordan to be the interaction of government agencies with the 
departments of banks in order to take actions and decisions necessary to create and develop the management capacity of the decision-makers in senior management at the institutional level, especially in light of the complexity of the work environment and the multiplicity of factors affecting the business environment. (Plumptre and Graham, 1999, p.2)

Management of the banks has to work on: (www.eyptsons.com)

1 - Lowering the cost of capital of the bank.

2 - Attracting investment, whether local or foreign.

3 - Reducing the exit of capital out of the country.

4 - Retard the growth and eradication of corruption to help in the growth of the national economy and lift it.

5 - To maximize profits and increase its financial position and its ability to ensure that shareholders' returns on their investments of financial and non-financial.

Studies have shown, and previous research that the understanding of management functions and follow management plans relating to decisions of financial and non-financial works to improve the performance of financial and nonfinancial and reduce the various risks and achieve high profitability of the bank through the preservation of their market share, leading to stuck customers the bank who are dealing with and increase their confidence and loyalty to him which pushes the wheel of the national economy and development by attracting foreign investments and domestic financial (Center for International Private Enterprise (2008 (CIPE), (Gopasamy, 1998 pp3-6) (Solomon, 2008, p15)

\subsection{Elements of the Application of Corporate Governance}

There is an urgent need at the present time to revisit the concept of corporate governance on the one hand and the accounting standards and the behavior and ethics of the profession of auditing on the other hand. As for the impact on the independence of auditors and increase the effectiveness of their performance as well as their role in evaluating the performance of management in the companies through to show the strengths and weaknesses of their performance.

A key component of institutional control and the presence of laws and regulations and legislation that outlines the rights and responsibilities of shareholders the right to vote and elect a board of directors and appoint or remove the external auditor. In addition to identifying strategic management of the Bank's future and the existence of systems of internal control and accounting efficient and effective, as well as the existence of an Audit Committee concerned with the control of the performance of management and the external auditor and the internal enjoying full independence and have full powers evaluate the performance of the administration of financial and non- financial, to ensure the transparency and credibility of financial information provided to shareholders and related parties the relationship of the bank employees, creditors, customers, government agencies... Etc.. (Matar, 2003, p4) (Guenther, 2003) (charter, 2003, p.1)

Many studies have shown that the success of the implementation of management strategies depends heavily on the careful analysis of the relationship that binds the parties related to the management and efficiency of the non-financial performance management, led by shareholders, employees, customers, depositors and creditors and other.. And that the relationship is characterized by clarity with management decisions about the continued development and improvement of their performance as well as the credibility and transparency in the presentation of the results of their work.

And that this is one of the pillars of the success of the management strategy in Jordanian banks where we note that the administration's relationship with its employees, its customers and its shareholders and others are integrated with the development and improvement of service delivery, which is intended to set the procedures and methods used to provide services to meet the wishes of customers in terms of quality, and is working to achieve the goals of the bank in terms of continued profitability as well as the achievement of the bank to put in a competitive business environment characterized by competition and advanced technology.

\section{Population and Study Sample}

The sample included a Population study on all commercial and Islamic banks in Jordan totaling (16 Banks), (guide banks in Jordan,2013, www.cbj.gov.jo), where the study aimed to executive management, sections and departments on the Application of Corporate Governance in those banks, as well as financial and accounting departments where. In order to get the information and data necessary to measure the objectives of the research and prove or disprove 
hypotheses, ten questionnaires were distributed to each bank and total (160) of them recovered form (150) found form of which (145) form suitable for analysis. Where the researcher analyzed the answers of the study sample standards used by the SPSS statistical system and to achieve the objectives of the study.

\subsection{Results Presentation}

This includes the presentation of the findings of the study, and after that, the researcher using descriptive statistics, containing mean and standard deviation to describe the study sample answers. Where the research analyzed the responses of a sample study of the scale used by the statistical system SPSS and to achieve the objectives of the study, and that by testing one sample T-test to test each of the hypotheses of the three sub to come to check the presence of a statistically significant difference between the mean and the median study tool in order to judge the study sample opinions about the sub- hypotheses. The Pearson coefficient was tested in order to test the relationship between each of the independent and dependent variables in the sub- hypotheses and main hypothesis at 0.05 level.

\subsection{Sources of Data Collection}

1 - Secondary sources: Books, scientific references and previous studies on the subject of the study.

2- Primary sources: the information was collected through a questionnaire design included on four axes, which dealt with the first axis demographic characteristics of the sample in order to reach health information and data derived from the opinions and answers them. While the second axis and the third and fourth to prove or disprove hypotheses of the study, which was measured hypotheses of the study and proved nor disproved through 23, 13,21, paragraph respectively.

3- A measure of the 5 point Likert scale in the preparation of this questionnaire was given the following weights:

\begin{tabular}{cc}
\hline Strongly agree & 5 \\
\hline Agree & 4 \\
\hline Neutral & 3 \\
\hline Disagree & 2 \\
\hline Strongly disagree & 1 \\
\hline & \\
\hline Low & $2,49-0,0$ \\
\hline Average & $3,49-2,5$ \\
\hline High & $5-3,5$ \\
\hline
\end{tabular}

\subsection{Analyzing the Results of Testing Hypotheses}

3.3.1 First Hypothesis: Jordanian Commercial banks and the Islamic banks do not apply corporate governance through identified for its principles and its components and steps

Table 1. The arithmetic mean and the standard deviation of a variable to measure the application of Jordanian banks to corporate governance through identified for its principles and its components and steps

\begin{tabular}{clcc}
\hline $\begin{array}{c}\text { Se. } \\
\text { No. }\end{array}$ & \multicolumn{1}{c}{ Paragraph } & $\begin{array}{c}\text { Standard } \\
\text { Deviation }\end{array}$ & $\begin{array}{c}\text { The } \\
\text { arithmeti } \\
\text { c mean }\end{array}$ \\
\hline & $\begin{array}{l}\text { Bank senior management working to identify the principles and } \\
\text { elements of corporate governance needed to be applied in Jordanian } \\
\text { banks. }\end{array}$ & 1.14127 & 3.9448 \\
\hline & $\begin{array}{l}\text { The department of the supreme banks to apply corporate } \\
\text { governance when to disclose non-financial performance in the } \\
\text { financial statements. }\end{array}$ & 1.31350 & 3.0621 \\
\hline 3 & $\begin{array}{l}\text { Bank senior management disclose their data and information about } \\
\text { the financial and non-financial users the right time and allow them } \\
\text { to field to discuss the financial position and operating the bank. }\end{array}$ & 1.26370 & 3.8552 \\
\hline & $\begin{array}{l}\text { Bank senior management disclose their data and information on the } \\
\text { financial and non-financial users and allows them to request } \\
\text { information and data necessary and essential and which serve their } \\
\text { decisions. }\end{array}$ & 0.88273 & 4.4828 \\
\hline 5 & $\begin{array}{l}\text { The board of directors of the bank the function of monitoring the } \\
\text { performance of senior management of the non-financial. }\end{array}$ & 1.13221 & 3.6069 \\
\hline
\end{tabular}




\begin{tabular}{|c|c|c|c|}
\hline 6 & $\begin{array}{l}\text { The board of directors of the bank the function of making decisions } \\
\text { concerning the management of the bank and its implementation. }\end{array}$ & 0.76483 & 4.5103 \\
\hline 7 & $\begin{array}{l}\text { The department of the bank and the board of directors to take } \\
\text { decisions related to the procedures to ensure the protection of the } \\
\text { different stakeholders with the bank. }\end{array}$ & 1.24530 & 2.0690 \\
\hline 8 & $\begin{array}{l}\text { The department of the bank and the board of directors to take } \\
\text { decisions related to the procedures to ensure the protection of their } \\
\text { interests at the expense of the interests of stakeholders. }\end{array}$ & 1.28086 & 3.2966 \\
\hline 9 & $\begin{array}{l}\text { There is talk about trades or decisions taken by senior management } \\
\text { was in the interests of the board of directors and owners at the } \\
\text { expense of the interests of other parties. }\end{array}$ & .64639 & 4.5241 \\
\hline 10 & $\begin{array}{l}\text { Information is displayed and the financial statements and } \\
\text { non-financial to all parties and sufficiently prior to the convening } \\
\text { regular meetings with other parties related with the bank. }\end{array}$ & 1.18963 & 3.7931 \\
\hline 11 & $\begin{array}{l}\text { The decisions of the senior management of financial and } \\
\text { non-financial in the bank aims to protect the market share of the } \\
\text { bank. }\end{array}$ & 0.78192 & 4.5379 \\
\hline 12 & $\begin{array}{l}\text { The decisions of the senior management of financial and } \\
\text { non-financial in the bank aims to raise the market share price of the } \\
\text { bank. }\end{array}$ & 1.14817 & 3.7103 \\
\hline 13 & $\begin{array}{l}\text { The decisions of the senior management of financial and } \\
\text { non-financial in the bank aims to make clear to all parties related to } \\
\text { the bank with market expectations, risks and competition. }\end{array}$ & 0.98188 & 3.9655 \\
\hline 14 & $\begin{array}{l}\text { The department of higher bank to maintain its good relations with } \\
\text { the outgoing auditors and government agencies and provide them } \\
\text { with data and financial information and non-financial performance } \\
\text { necessary for a transparent and credible and timely. }\end{array}$ & 1.08490 & 3.7724 \\
\hline 15 & $\begin{array}{l}\text { The department of higher bank to make decisions related to public } \\
\text { safety. }\end{array}$ & 0.95557 & 3.7724 \\
\hline 16 & $\begin{array}{l}\text { The department of higher bank to take decisions relating to the } \\
\text { preservation of the environment (especially the economy). }\end{array}$ & 1.24845 & 3.6621 \\
\hline 17 & $\begin{array}{l}\text { The department of higher bank to make decisions aligned with the } \\
\text { legal requirements imposed by the organizers of the bank's business } \\
\text { (such as the central example). }\end{array}$ & 0.98834 & 3.8483 \\
\hline 18 & $\begin{array}{l}\text { Formed senior management in the banking committee or } \\
\text { committees will ensure follow-up and operational performance of } \\
\text { the staff and review their programs in order to ensure efficiency and } \\
\text { develop that require it. }\end{array}$ & 0.86337 & 4.1793 \\
\hline 19 & $\begin{array}{l}\text { Operate the top management of the bank to provide a system of } \\
\text { internal control efficient and effective work to ensure the safety and } \\
\text { control of financial and accounting procedures in the bank. }\end{array}$ & 0.64416 & 4.5586 \\
\hline 20 & $\begin{array}{l}\text { The various committees formed by the senior management of the } \\
\text { bank to discuss the operational management performance and give } \\
\text { them different notes transparently in order to raise the efficiency of } \\
\text { the operational performance of senior management and the } \\
\text { preservation of its financial position and market share. }\end{array}$ & 1.21323 & 3.8552 \\
\hline 21 & $\begin{array}{l}\text { Operate the top management of the bank and the board of directors } \\
\text { to ensure the performance of various departments in the bank and } \\
\text { control it constantly to ensure good implementation of various } \\
\text { management decisions. }\end{array}$ & 0.77113 & 4.5655 \\
\hline 22 & $\begin{array}{l}\text { The application of corporate governance in the bank to increase } \\
\text { understanding and awareness of senior management and the board } \\
\text { of directors of the non-financial metrics when evaluating } \\
\text { performance. }\end{array}$ & 1.16605 & 3.7931 \\
\hline
\end{tabular}




\begin{tabular}{lll}
\hline 23 & $\begin{array}{l}\text { Keep senior management at the bank on the bank's reputation and } \\
\text { market share through the development and evaluation of the various } \\
\text { services offered by the bank. }\end{array}$ & 0.98188 \\
\hline Total & 0.53927 & 3.0345 \\
\hline
\end{tabular}

As noted from the Table 1 above. The members of the sample confirmed that the Jordanian banks interested in the application of the rules of corporate governance, where is senior management interested in the application. As the members of the sample answers to the first paragraph of arithmetic mean (3. 9448) with a standard deviation (1.14127) also confirmed that the members of the sample answers to the second paragraph which showed that departments of Jordanian banks concerned and interested with non-financial performance to lift its value by applying corporate governance where the average answer of the members of the sample on the previous paragraph (3.0621) with standard deviation (1.31350).

While the answers of the members of the sample to paragraphs $(3,4,10,14)$, the attention of the administration to deliver necessary information for users of all types, whether financial or non-financial, adequate and an appropriate credibility and transparency when the need for it. As well as maintaining relations with them, where the arithmetic mean of the previous paragraphs (3.8552) (4.4828), (3.7931), (3.7724), respectively with standard deviation (1.26370), (0.88273), (1.18963), and (1.08490).

While the paragraphs $(5,6)$ came to make sure that the board of directors of the bank is concerned with the control function on the performance of the department without interference from different where taken or implemented. This is an evidence of the application of the rules of corporate governance, and responsibilities of the board of directors of the Bank, where the arithmetic mean (3.6069) and (4.5103) respectively with standard deviation (1.13221) and (76483).

The answers to the sample on the paragraph (7) where a neutral arithmetic mean is (2.0690) With a standard deviation (1.24530), on the basis that the sample members agree to take various resolutions that would raise the financial performance of the bank on the protection of the different interests and not the role of the Council of Administration in decision-making.

While their answers to paragraphs $(8,9)$ Attention to exile the concept of protection of the interests of the Bank and various administrative decisions which are in their interests without concern for the interests of the administration itself or the board of directors. The arithmetic mean responses for both paragraphs (3.2966) and (4.5241) respectively, with standard deviation (1.28086) and (64639) respectively.

The paragraphs $(11,12,13,23)$ came to affirm the attention of the management of the bank with financial and non-financial decisions that would improve the reputation of the Bank from Meanwhile, on the other hand, as well as to maintain its sustainability through their interest in lifting the price of shares the bank and protect market share, as well as to study the risks and prospects for the future and take the necessary reserves to face them, where the arithmetic mean for the previous paragraphs (4.5379) (3.7103), (3.9655) and (4.0345) respectively with standard deviation (.78192) (1.14817), (98188) and (.98188) respectively.

As for the non-financial performance of the management of banks, relating to the environment and conservation, the answers of the sample members on paragraphs $(15,16)$ to confirm the interest of the performance of the bank to achieve this, Answers of the sample on the previous paragraphs (3.7724) and (3.6621) respectively with standard deviations (.95557) and (1.24845) respectively.

As the answers of the sample members relating to paragraphs $(17,19)$ concerning the non-financial performance of the management of banks in making decisions In line with the requirements of the law and the system of internal control to confirm the integrity of the proceedings financial and accounting, the answers of sample members have confirmed that (3.8483) and (4.5586) respectively, with standard deviations (.98834) and (.64416) respectively.

Regarding the non financial performance of the management of the Bank through the formation of various committees that would follow-up the performance All operational departments in the bank, whether in the departments and central upper or lower, the Answers of the sample confirm it through the paragraphs $(18,20,21)$ the arithmetic mean (4.1793), (3.8552) and (4.5655) respectively with standard deviations. (86337), (1.21323) and (.77113) respectively. While the paragraph (20) confirmed on the removal of bias in answers to members of the sample on the paragraphs of the second hypothesis, in order to ensure managerial operational decisions, which relate to the formation of various committees that would increase the efficiency of the functioning of the different departments of the bank. 
3.3.2 Testing the First Hypotheses: Jordanian Commercial banks and the Islamic banks do not apply corporate governance through identified for its principles and its components and steps.

Table 2

\begin{tabular}{cccc}
\hline T calculated & T tabulated & T significance & Result HO \\
\hline 19.805 & 1,9971 & 0,000 & Reject \\
\hline
\end{tabular}

The use of one sample t test. to test the hypothesis above and notes of the results of the analysis shown in table (2) that the value of ( $\mathrm{t}$ calculated) When average default (3) is equal to (19.805) and in terms of statistics (0.000) is higher than the value of (T Tabulated) 1,9971, which is the value statistically significant at the level of statistical significance $(0,05 \geq a)$ Accordingly, we reject the Null hypothesis (HO) and accept alternative hypothesis, which provides: Jordanian Commercial banks and the Islamic banks do apply corporate governance through identified for its principles and its components and steps.

3.3.3 Second Hypothesis: Non-financial performance of the higher level of management in Jordanian Commercial banks and the Islamic banks are not affected by application of Corporate Governance.

Table 3. The arithmetic mean and the standard deviation of a variable to measure the acceptance level of the sample members regarding the degree of effect of the senior management of the Jordanian banks by non financial performance by applying corporate governance

\begin{tabular}{|c|c|c|c|}
\hline $\begin{array}{l}\text { Se. } \\
\text { No. }\end{array}$ & Paragraph & $\begin{array}{c}\text { Standard } \\
\text { Deviation }\end{array}$ & $\begin{array}{l}\text { The } \\
\text { arithmetic } \\
\text { mean }\end{array}$ \\
\hline 1 & $\begin{array}{l}\text { The application of corporate governance make decisions of senior } \\
\text { management are made concerning to deal with their clients in } \\
\text { transparency by clarifying its strategy to provide different services } \\
\text { to them Current and future. }\end{array}$ & 1.11568 & 3.8621 \\
\hline 2 & $\begin{array}{l}\text { The application of corporate governance make senior management } \\
\text { make decisions concerning to deal with their clients in } \\
\text { transparency through participate their opinion to know their } \\
\text { wishes and requirements on how to perform and deliver services to } \\
\text { them. }\end{array}$ & .98368 & 3.8207 \\
\hline 3 & $\begin{array}{l}\text { The application of corporate governance make senior management } \\
\text { make decisions to find easy communication direct channels with } \\
\text { customers. }\end{array}$ & 1.26336 & 3.7103 \\
\hline 4 & $\begin{array}{l}\text { The application of corporate governance make senior management } \\
\text { make decisions to decide specialized area to evaluate client } \\
\text { satisfaction about services provided to them. }\end{array}$ & 1.02343 & 3.9655 \\
\hline 5 & $\begin{array}{l}\text { The application of corporate governance make senior management } \\
\text { make decisions concerning the protection of social and ethical } \\
\text { values when dealing with customers and to provide different } \\
\text { services to them. }\end{array}$ & .86536 & 4.2897 \\
\hline 6 & $\begin{array}{l}\text { The application of corporate governance make senior management } \\
\text { make decisions about the performance of the services provided to } \\
\text { clients according to their wish. }\end{array}$ & 1.04000 & 3.9586 \\
\hline 7 & $\begin{array}{l}\text { The application of corporate governance make senior management } \\
\text { make decisions relating to the study of their competitors and how } \\
\text { to develop and evaluate programs and the performance of their } \\
\text { services delivered to clients. }\end{array}$ & .86702 & 4.2966 \\
\hline 8 & $\begin{array}{l}\text { The application of corporate governance make senior management } \\
\text { make decisions which increase their competitiveness and } \\
\text { development through training of staff to be able to move with } \\
\text { banking technological development. }\end{array}$ & 1.14638 & 3.8621 \\
\hline 9 & $\begin{array}{l}\text { The application of corporate governance make senior management } \\
\text { make decisions relating to increase loyalty of their staff by } \\
\text { involving them in many administrative decisions concerning the }\end{array}$ & .92589 & 4.1034 \\
\hline
\end{tabular}




\begin{tabular}{|c|c|c|c|}
\hline 10 & $\begin{array}{l}\text { The application of corporate governance make senior management } \\
\text { make decisions concerning the Protection of social and ethical } \\
\text { values of its employees and workers. }\end{array}$ & 1.09343 & 3.9241 \\
\hline 11 & $\begin{array}{l}\text { The application of corporate governance make senior management } \\
\text { make decisions concerning the developing relations with their staff } \\
\text { on the high degree of justice and equality by giving them } \\
\text { incentives and rewards commensurate with those submitted to the } \\
\text { board of directors. }\end{array}$ & .98781 & 3.8690 \\
\hline 12 & $\begin{array}{l}\text { The application of corporate governance make senior management } \\
\text { make decisions concerning the medical Insurance social security } \\
\text { of their staff. }\end{array}$ & 1.27483 & 3.7655 \\
\hline 13 & $\begin{array}{l}\text { The application of corporate governance make senior management } \\
\text { make decisions concerning to make the technology necessary for } \\
\text { the performance of staff members on the high degree of efficiency, } \\
\text { accuracy and speed for best achievement. }\end{array}$ & 1.02343 & 3.9655 \\
\hline 14 & $\begin{array}{l}\text { The application of corporate governance make senior management } \\
\text { make decisions relating to the holding of Periodic meetings with } \\
\text { staff members to be able to evaluate the performance of the Board } \\
\text { of Directors. }\end{array}$ & .86536 & 4.2897 \\
\hline 15 & $\begin{array}{l}\text { The application of corporate governance make senior management } \\
\text { make decisions concerning the Disclosure of financial and } \\
\text { non-financial data and at time allows for evaluation of the } \\
\text { performance of Financial and non-financial departments by the } \\
\text { shareholders. }\end{array}$ & 1.03057 & 3.9793 \\
\hline 16 & $\begin{array}{l}\text { The application of corporate governance make senior management } \\
\text { make decisions concerning the Disclosure of financial and } \\
\text { non-financial data and at time allows for evaluation of bank risk. }\end{array}$ & .86702 & 4.2966 \\
\hline 17 & $\begin{array}{l}\text { The application of corporate governance make senior management } \\
\text { make decisions concerning the Disclosure of financial and } \\
\text { non-financial data and at time allow the assessment of the capacity } \\
\text { of Bank to meet their current and future obligations. }\end{array}$ & 1.01370 & 3.9862 \\
\hline 18 & $\begin{array}{l}\text { The application of corporate governance make senior management } \\
\text { make decisions to find easy and direct channels of communication } \\
\text { to the management of the Bank and its board of directors and } \\
\text { parties that have relationship with the Bank (shareholders, } \\
\text { creditors, governmental bodies). }\end{array}$ & .86364 & 4.2828 \\
\hline 19 & $\begin{array}{l}\text { The application of corporate governance make senior management } \\
\text { clarify the non financial performance nature of the department of } \\
\text { the Bank and current and future risks faced by the Bank of the } \\
\text { Parties which have relationship with the Bank (shareholders, } \\
\text { creditors, governmental bodies). }\end{array}$ & 1.02703 & 3.9724 \\
\hline 20 & $\begin{array}{l}\text { The application of corporate governance make senior management } \\
\text { make decisions to clarify the non financial performance nature of } \\
\text { the department of the Bank and the Financial position, and } \\
\text { competitiveness by banks other. }\end{array}$ & .86536 & 4.2897 \\
\hline \multirow[t]{2}{*}{21} & $\begin{array}{l}\text { The application of corporate governance make senior management } \\
\text { to hold periodic meetings with the parties of the relationship with } \\
\text { the Bank (shareholders, creditors, governmental bodies...) explain } \\
\text { them non- Financial performance to the high level management } \\
\text { and to get their feedback on their assessment of senior } \\
\text { management in order to raise the efficiency of the non financial } \\
\text { performance of the bank department. }\end{array}$ & .86536 & 4.2897 \\
\hline & Total & .77586 & 4.0371 \\
\hline
\end{tabular}


Evidenced by the answers of respondents on the vertebrae (Table 3) above in relation to the decisions of operational management relating to Bank and interest in dealing with transparency and clarity on strategies for different bank for the provision of services to them, whether in the short or long term, as well as management's attention the information feedback of them to get their wishes their requirements and delivery mechanism for them and make decisions regarding development and continuous improvement that would maintain customers and increase their loyalty to the bank. Answers came respondents to paragraphs $(1,2,6.7)$ and averaged calculation (3.8621) (3.8207) (3.9586) and (4.2966), respectively, and standard deviations, respectively (1.11568), (0.98368), (1.04000) and (0.86702).

With regard to how to get feedback from customers and evaluate their satisfaction and acceptance of the services provided to them was that of making management decisions related to finding convenient channels associated with customers working to achieve it. Answers came respondents paragraphs (3.4) to confirm that the arithmetic means (3.7103) and (3.9655), respectively, and standard deviations (1.26336) and (1.02343), respectively.

With regard to the decisions of operational management in the training of staff and take their views on the shortcomings they have and the protection of moral and social values to him as well as the provision of rewards programs and incentives, medical insurance and social security for them and provide the technology needed for their performance and hear their views on the performance of management and decisions concerning them which would raise the efficiency of the performance of staff towards providing excellent services and competition for customers working to achieve their desires and requirements as this has a direct impact on the increase in the Bank's profitability and sustainability, which achieves the other hand, loyalty is required and by the staff of the bank, which is reflected directly on how to meet the desires and requirements of the customers and to maintain the market share of the Bank and even work on the increase, which confirmed the answers of respondents to paragraphs $(8.9,10$, $11.12,13,14)$ and averaged calculation (3.8621) (4.1034) (3.9241) (3.8690) (3.7655) (3.9655) and (4.2897), respectively, and standard deviations (1.14638), (0.92589), (1.09343), (0.98781), (1.27483), (1.02343) and (0.86536), respectively.

The paragraphs $(15.16,17,20)$ came to confirm the answers of respondents around the operational management decisions relating to other parties associated with the bank, shareholders, creditors and others ... And the delivery of the necessary information to evaluate the performance of financial management and non- financial and find channels of communication with them easily where it came from answers of respondents to the preceding paragraphs averages calculation (3.9793) (4.2966) (3.9862) and (4.2897), respectively, and the standard deviations (1.03057), (0.86702), (1.01370) and (0.86536), respectively.

The answers came on the paragraphs of the sample $(18,19,21)$ arithmetic means (4.2828) (3.9724) and (4.2897), and standard deviations (0.86364), (1.02703) and (0.86536), respectively, to confirm that the management performance non- financial to the bank enhances its ability to disclosure of related parties associated with the bank for the necessary data that will increase their ability to assess the risks of the bank and its ability to meet its current and future, and its ability to compete and that by holding meetings with them to get their views and comments on the performance of operational Management in order to raise the efficiency of operational performance management.

\subsubsection{The Second Hypothesis Test}

Table 4. Non-financial performance for higher level of management in Jordanian commercial banks and Islamic banks is not affected by applying corporate governance in

\begin{tabular}{cccc}
\hline T calculated & T Tabulated & T significance & Result HO \\
\hline 16.096 & 1,9971 & 0,000 & Reject \\
\hline
\end{tabular}

Test was used ONE SAMPLE T-TEST to test the hypothesis above and notes from the results of the analysis described in the Table 3 that the value of (T calculated) when the average default (3) equal to (16.096) and in terms of statistics (0000) which is higher than the value of (T Tabulated) 1.9971, a value statistically significant at the level of statistical significance $\left(a^{3} 0,05\right)$ Accordingly, we reject the Null hypothesis (HO) and accept the alternative hypothesis, which states: Non-financial performance for higher level of management in Jordanian commercial banks and Islamic banks is affected by applying corporate governance in.

Through the analysis of the results of the previous hypotheses we note the values of alpha coefficients for the variables of the study explained to choose the normal distribution of the variables of the study are as follows: 
Table 5. The values of alpha coefficients for the variables of the study

\begin{tabular}{cc}
\hline Variable & Value $\alpha$ \\
\hline The first hypothesis & 0,873 \\
\hline The second hypothesis & 0,966
\end{tabular}

It is noted that all the paragraphs of the values of alpha (a) is greater than the acceptable $(60 \%)$, where the value for the identification of a whole 0.956 , reflecting the stability of the measurement tool, and this represents a ratio acceptable for the purposes of the stability of the internal consistency, and by acceptable for the purposes of analysis so that exceeded the agreed minimum of constancy.

\section{Conclusions}

Through both sides of the theoretical research and the field has been reached to a set of conclusions was the most important:

1 - The study showed that the departments of commercial and Islamic banks in Jordan are concerned with non-financial performance along with the financial performance and is interested in increasing its efficiency and effectiveness through the application of corporate governance in banks concerned performance.

2 - The study proved the commitment of the departments of commercial and Islamic banks in Jordan deliver financial information and non-financial users of different assortment of credibility, transparency and the right time as well as the preservation of their mutual relations with them periodically when you need appropriate degree.

3 - The study proved that the boards of directors in commercial and Islamic banks in Jordan involved in the control of the performance of senior management without the intervention of various decisions taken by the senior management of low degree.

4 - The study proved that the non-application of corporate governance and impose its concepts and its components and principles in commercial and Islamic banks in Jordan would reduce the efficiency and effectiveness of the performance of senior management to make decisions that works to protect the interests of the related parties with the bank without paying attention to the interests of the administration itself or the interests of the Board of Directors in it.

5 - The study proved that there is an appropriate degree of attention by senior management application of corporate governance in commercial and Islamic banks in Jordan would assist management in particular, to make decisions about financial and other lead to the lifting of the bank's reputation in the market competition and increase profits and continuity.

6 - The study supported the role of corporate governance in monitoring the performance of non- financial departments of commercial and Islamic banks in Jordan on the following decisions:

- Dealing with customers in a transparent and easy to find channels of communication with them and work to appease them and to meet their desires.

- Decisions concerning the environment and conservation.

- Increase staff loyalty has through the protection of moral and social values and well-being, and their involvement in many of the administrative decisions.

- provide the means and procedures for the application of paramount technology in the performance of the service.

- Disclosure of financial and non- financial transparency and timely manner.

- Dealing with the various parties concerned with the bank and easy to find channels of communication with them periodically.

7 - The study showed that the application of corporate governance leads to make the departments of banks operating on the decisions of financial and non-financial copes with legal requirements and provide a system of internal control confirms the safety of financial and accounting procedures.

\section{Recommendations}

The study found through analysis of the responses of the sample and the results to a set of recommendations, the most important of which:

1 - Increasing the understanding and management by the departments of commercial and Islamic banks in Jordan to deepen the concepts and rules of corporate governance that will emphasize the delivery of financial information and non- financial performance of the different parties (Kalmsahmin staff and increase and government agencies, 
etc.) integrated with Jordanian banks the right time and with transparency and clarity.

2 - Work on the application of corporate governance in commercial and Islamic banks in Jordan so as to more effectively work on raising the efficiency of the performance of senior management in making financial decisions and non-financial.

3 -Minimize the impact of the boards of management in commercial and Islamic banks in Jordan decisions on financial and non- financial matters taken by senior management in order to protect the interests of the other parties related with the bank.

4 - Application of Corporate Governance in commercial and Islamic banks in Jordan and binding enough to raise the capacity of Jordanian banks and increase their competitiveness in the labor market to maintain the continuity and maximize profits.

7 - Increase the text of laws and legislation imposed by the government and the competent application of corporate governance in Jordanian banks in particular and the public shareholding companies, in general, because of its active role in the increase and raise the efficiency of the performance of the senior management of financial and non-financial.

8 - Adopting the concept of corporate governance by the Association of Chartered Accountants of Jordanians and conduct courses and programs for auditors in order to increase their skills and prepare them for dealing with the concept of corporate governance mechanism and its application in various Jordanian shareholding companies, especially banks from them.

9 - Increasing attention competent authorities to monitor the performance of departments of commercial and Islamic banks in Jordan and financial and non-financial consideration of the information and data submitted to the relevant parties and the study of their accuracy and speed to answer their queries.

10 - The need for senior management in commercial and Islamic banks in Jordan to disclose their objectives and programs of financial and non-financial to be achieved are clear to all parties dealing with them in order to be studied and evaluated accurately and timely.

11 - Commercial and Islamic banks in Jordan to manage the disclosure of the organizational structure of all the different departments and the statement of the responsibilities and powers of each of them as this has a clear impact in determining the financial metrics and non-financial performance and the degree of monitoring and evaluation.

12 - Increased attention of senior management in commercial and Islamic banks in Jordan to provide an effective system for the transmission of reports and information necessary to achieve the objectives of corporate governance and assess the performance of senior management of financial and non- financial by the parties deal with them as, employees and customers, government agencies and others.

\section{References}

Arab Society of Certified Accountants, ASCA, Tlal Abo- Ghazaleh. (2006). A guide to Corporate Governance. p.5.

Bashir, Mohammad. (2003). Institutional control and auditors, the fifth professional scientific conference entitled Control and institutional continuity established, Oman 23-25 September.

Basil Committee on Banking Supervision. (1999, 2005, 2006). Enhancing Corporate Governance for Banking Organizations. Basil.

C.T. Horngren, Alnoor Bhimani, George Foster, \& Srikant. Datar. (1999). Management and cost accounting, prentice Hall Europe.

Center for International Private Enterprise, CIPE. (2008). Corporate Governance in Emerging Markets Cairo, p.6.

Charter. (2003). Audit committee. A Governance publishing, V.K, files Html, p.1.

Cokins, Gary. (1996). Activity- Based cost management, making it work.

Dahmash, \& Naim Abu zer, Afaf. (2003). Corporate Governance and its relationship with audit and accounting and auditing profession, the fifth professional scientific conference of the Association of Chartered Certified Accountants Jordanian, Oman 23-25 September.

Directory of Banks in Jordan, 2013. Retrieved from www.cbj.gov.jo

European shadow financial Regulatory committee [ESFRC). (2003). London, July. Retrieved from www.google.com

F., Ahmad Hilmi. (2003). Control and institutional dimensions of development in the exercise of the profession of internal auditing, the fifth professional scientific conference of the Association of Chartered Certified 
Accountants Jordanian, Oman 23-25 September, p6.

Frechette, Louise. (1999). Speech to me world Conference on Governance, Manila, May, p31.

Gopasamy, N. (1998). Corporate Governance, The New paradigm (1 ${ }^{\text {st }}$ ed.). Wheeler Publishing, pp.3-6.

Guenther, Kin. (2003). Effective Web governance Structures, Industry Preview Online, February. Retrieved from www.findartcles.com

Hampel, Ronnie. (1998). Committee of corporate Governance. Gee publishing Ltd, January final report.

John Innes, Falconer Mitchell, \& Takeo Yoshikawa. (1994). Activity Costing for Engineering. John wiley and Sons, Inc.

Kayed, Zuhair Abdul Karim. (2003). Governance, Issues and Applications. The Arab Organization for Administrative Development, League of Arab States.

Klien. (2002, April). Economic Determinates of Audit committee independence. The Accounting Review, 77(2).

Maher, Ahmad. (2007). The development of organizations: the scientific evidence for the restructuring and management excellence and change management. University House Alexandria, p543.

Menar Ayut. (2007). Corporate and Dividend policy. Munich personal REPEC Archive.

Merchat, Kenneth. (1998). Modern management Control Systems. Prentice Hall, pp.72-73.

Mirag, Abdul Qadir, \& Abdul Hafeez, Ahmed. (2007). Corporate Governance in the banking sector and the financial and their role in establishing the rules of transparency. Scientific Symposium of the accounting department, the Saudi capital market look independent, King Khalid University, Saudi Arabia RR: 12.14.

Mohammed Mattar. (2003). The role of accounting information disclosed in promoting activation of institutional control. Scientific Conference of the Association of Professional fifth of Chartered Accountants of Jordanians, p4.

Nagel, Micha, \& Rigatuso, Chris. (2003). Improving Corporate governance: A Balanced Scorecard Approach. Retrieved July, 2003, www.ovacl.com

Nokomura Masoa. (2001). Japanese Governance and Macroeconomic problems. Retrieved July 14, 2004, www.oracl.om

OECD. (1999). OECD'S Definition Consistent with the one presented by Cadbury, April.

Oskar Kowalewski. (2007). Corporate Governance and Dividend policy in Poland. German Institute for Economic Research.

Plumptre, T., \& Grahm, J. (1999). Governance and Good Governance, International and Aboriginal perspectives. Institute on Governance Ottawa, Canada, p.2.

Ricardo, Bebczuk. (2005). Corporate Governance and Ownership: Measurement and Impact on Corporate Performance and Dividends policies in Argentina. Inter- American Development Bank.

Sakka, Khaled. (2004). Corporate Governance in the Jordanian banking industry. Journal of Jordanian banks, 23(4), 38-43.

Silvia and Amaro. (2005). Framework for Assessing the Quality of Bank Management and Governance. Central Bank at Brazil, p.1

Sobh, Mohammed. (1996). Does professional managers are always in favor of the shareholders. Journal of the Faculty of Commerce, Ain Shams University, Cairo.

Suleiman, Mohammed Mustafa. (2008). Corporate governance and the role of board members and executives. University House, Alexandria, p15.

The Union of Arab Banks. (2003). Good governance in the banking and financial institutions in the light of the Arab internationally accepted standards. Beirut pp.40-42.

United Nation Development program (UNDP). (1997). Governance for Sustainable Human Development. A Undo policy Document, N,Y, p.3

University of Technology Sydney (VTS). (2002). Center for Corporate Governance. Retrieved from www.google.com

Zhang, Haiyan. (2008). Corporate Governance and Dividend Policy, A comparison of Chinese firms Listed I Hang Kong and in the Mainland. China Economic Review. 